\title{
The Aims of Career Development Policy: Towards a Comprehensive Framework
}

\author{
Peter J. Robertson
}

Edinburgh Napier University, UK.

\begin{abstract}
This chapter will explore and question the aims of public policy for career development. A case will be made for a broader conception of the socially desirable outcomes from career interventions. Drawing on the United Nations sustainable development goals, a systematic framework of six types of policy goal for career development services will be proposed: (i) labour market goals, (ii) educational goals, (iii) social equity goals, (iv) health and well-being goals, (v) environmental goals, and (vi) peace and justice goals. The latter three categories represent new or relatively neglected areas of focus. Cross cutting themes of social justice, sustainability, and societal change will be highlighted.
\end{abstract}

Key words: Career development; development goals; public policy; social justice; sustainability.

\section{Introduction}

From its origins in the early $20^{\text {th }}$ century, career development work (then known as vocational guidance) has never been a purely economic instrument. It has been motivated by social concerns from the outset (Brewer, 1942; Peck; 2004; Savickas, 2008). Some of its pioneers in the UK, USA and Germany could be characterised as social reformers or philanthropists (Savickas, 2009), and the earliest government interventions are rooted in their contributions. Serious academic study of public policy for career development work became established 
much later, in the 1990s (notably Watts, 1996a). The idea that career interventions could offer wider social benefits was sketched out by Killen, Watts and Kidd (1999). By the early years of the $21^{\text {st }}$ century, a consensus emerged that the aims for public policy in career development could be categorised into three families of goals:

1. Labour market goals: To facilitate effective functioning of the labour market, matching individuals to work that suits them, and reconciling the supply for labour to the demand.

2. Educational goals: To facilitate effective functioning of the education and training system, to promote skills development and lifelong learning, and to smooth transitions from education into the labour market.

3. Social equity goals: To promote social inclusion and equality of opportunity.

This threefold distinction is evident in complementary international reviews of policy: in developed nations by the OECD (2004); in middle income nations and emerging economies by the World Bank (Watts \& Fretwell, 2004); and in European Union member nations (Sultana, 2004). It is also evident in an associated academic discourse (Watts, 2008; Watts \& Sultana, 2004). It continues to be prominent in international thinking (International Centre for Career Development in Public Policy [ICCDPP], 2019). Nonetheless labour market considerations continue to be in the foreground of government thinking about the purpose of career development policy, with broader educational and social equity goals sometimes becoming secondary or supportive to an economic agenda.

Whilst this body of work provides a helpful starting point to characterise the relevant government aims for career development policy, it is problematic because it addresses what is; not what could be. It draws on studies of what governments do and say that they do. It does not seek to outline the full potential range of socially desirable objectives for career 
development policy. In order to understand the full scope of possible purposes for career development policy, it is necessary to identify a taxonomy of policy goals that is credible, authoritative, current, and of relevance worldwide. Such a framework is provided by the $U N$ Sustainable Development Goals (United Nations, 2015), which defines shared international policy objectives for the year 2030. These replace the UN Millenium Development Goals, and it is the responsibility of nation states to implement them. Many nations have adopted the goals, along with the European Union (2017).

\section{The UN Sustainable Development Goals}

The UN goals have begun to influence conceptions of career development. Professor Jean Guichard, as UNESCO Chair in Lifelong Career Counseling led a series of activities that culminated in a conference at the University of Wroclaw in 2016 which concluded that practitioners should develop interventions in line with the UN goals (Cohen-Scali et al., 2018). Cohen-Scali (2018) suggests that career development work should integrate new societal challenges into its aims, including population growth, climate change, loss of biodiversity, inequality in access to resources, and access to decent work. The Sustainable Development Goals may expand our conception of the purposes of career development in a way that has global relevance, credibility, and currency. The framework offers an additional advantage: it does not privilege Western high-income economies. It is developed with low and middle-income economies very much in mind, whilst retaining relevance to prosperous nations. The goals are reproduced in table 1 (United Nations, 2015, p. 14/35).

\section{INSERT TABLE 1 AROUND HERE}

The potential aims of career development policy can be identified using the UN framework. It is clear that career development is not relevant to all the goals, and pertains more to some than to others. Nonetheless, the number of goals to which career development has some 
bearing is striking. The UN structure can be partially collapsed to produce an adequate classification for the goals of career development policy, that is simple but broadens the scope of current thinking. A six-fold framework is proposed here: (i) labour market goals, (ii) educational goals, (iii) social equity goals, (iv) health and well-being goals, (v) environmental goals, and (vi) peace and justice goals.

\section{Labour Market Goals}

This category relates directly to Goal 8: Promote sustained, inclusive and sustainable economic growth, full and productive employment and decent work for all. Employment related objectives are inevitably central concerns for career development policy. The economic considerations are directly addressed by Dodd and Percy (in this volume), so this important area can be dealt with briefly here.

The influence of neoliberalism on career development policy discourse is far reaching (Irving, 2018). This discourse tends to frame people as serving a macro-economic purpose, but tends to neglect the converse view that the purpose of the economy is to serve people and enable them to meet their basic needs and lead a meaningful life. It is therefore important that the UN goal balances economic growth with concern for people having access to good quality employment. Issues of decent work are explored by Gutowski, Blustein, Kenny and Erby (in this volume). Promoting access to work, particularly for youth at risk of unemployment, has been a goal of career development services from their very earliest inception (Peck, 2004).

Goals 1 and 2 relate to the eradication of poverty and hunger. In recent years some theorists have been arguing that notions of 'career' are not meaningful to people who are struggling to put food on the table, and for whom notions of choice in life seem to be an unattainable middle class ideal. Alternatives terms have been suggested, notably 'livelihood planning' 
(Arulmani \& Kumar, 2009; Sultana, 2017) as a more pragmatic label for helping those whose face daily challenges of economic survival, particularly in low to middle income economies.

\section{Educational Goals}

Policy goals related to learning are well established in the career development field. This area is highlighted by UN Goal 4: Ensure inclusive and equitable quality education and promote lifelong learning opportunities for all. Educational issues are explored elsewhere in this volume, so again this can be dealt with briefly here.

There has been some hollowing out of educational goals for career development policy towards an emphasis on raising attainment, the development of skills for industry, and on preparing students to transition from the education system into work by embedding generic employability skills and attributes. There is a tendency to conflate career development policy with vocational education and training (VET) policy, subsuming the former under the latter (Watts, 2009). In a neoliberal conception, the VET system enables individuals to serve an economic growth agenda. Hooley (in this volume) explores how this human capital development agenda has influenced conceptions of schooling and careers.

Whilst the technocratic function of education has its place, this neglects the full meaning of education to its participants, and its wider value to society. Individuals may look to education for personal growth and transformation, access to social (as opposed to vocational) status, for interest, for cultural enrichment, to build or reforge their identity, and to make friends or find partners. More specifically work-related or career education need not be narrowly functional in preparing pupils and students for employment (Sultana, in this volume). The UN goal is framed in terms of access and inclusion, not in terms of economic instrumentality, so accommodates a broader vision of the role of education. 


\section{Social Equity Goals}

Social equity goals relate to fair access to career opportunities, and the equitable distribution of life chances across the population. This means equity with respect to social categorisation primarily by gender, socio-economic status, race, ethnicity, religion, age, sexuality/gender identity, or migration. This is, and will remain, a central concern of career development work.

Gender continues to have a great influence in determining the roles that individuals adopt in relation to formal and domestic work (Kantamneni, 2014). So, the UN Goal 5: Achieve gender equality and empower all women and girls is clearly relevant here. Women are less likely to participate in the global labour market (ILO, 2018). They face four main issues when they do: pay inequality; occupational segregation into traditionally female work roles; under-representation in senior, prestigious or powerful jobs; and sexual harassment in the workplace (Bimrose, 2001, 2004). With biographies that often interweave child-rearing, caring roles and home-making with participation in formal employment, women's careers may be more complex than those of men (Bimrose, Watson, McMahon, Haasler, Tomassini \& Suzanne, 2014).

In addition, the UN Goal 10: Reduce inequality within and among countries is explicitly relevant. In recent years persuasive evidence has been produced for growing economic inequalities (Piketty, 2014; Stiglitz, 2013) driven by a combination of globalisation, new technologies, and widespread adoption of government policy underpinned by neoliberal ideologies. Similar factors are at work across many nations, mitigated to a greater or lesser extent by government intervention. These issues present a challenge to services engaged in career development work. Roberts (2005) claims that career development profession is incapable of addressing issues of class, due to its reliance on individualistic psychological 
concepts. But there have been moves in psychology to expand the discipline to recognise and respond to issues of poverty and inequality (Ali, 2014; Blustein, 2006, 2014).

Since the 1960s and 70s there has been a progressive extension of human rights and employment rights to groups that are potentially disadvantaged in the labour market. Nonetheless substantial asymmetries remain between demographic and social groups in society. This extensive range of issues is summarised very briefly below.

Race, ethnicity and religion: Whilst developed economies have made good progress in establishing legislative frameworks that prevent limit racial oppression, work continues to be an environment in which racial inequality is evident (Flores, 2014). Tensions associated with issues of religion and ethnic identity are dynamic and problematic in many societies although they manifest themselves uniquely in every nation.

Migration: Mobile populations have distinctive career experiences and often encounter considerable challenges. For example, Roma (travellers) and refugees are particularly disadvantaged at work (ILO, 2014). The career development issues facing migrant, and their support needs have only recently become an important focus of study (see Newman, Bimrose, Nielsen \& Zacherd, 2018).

Older workers: A convergence of demographic, social, cultural and economic factors in developed economies have led to working lives being extended. Retirement has become a longer and more complex life transition. This has led to greater focus on older workers as a potential service user group for career development research and intervention (Launikari, Lettmayr \& van Loo, 2011; Sterns \& Sterns, 2014).

Disability: Around $15 \%$ of the world's population has a disability: their educational achievement and levels of economic participation are substantially reduced compared to the 
non-disabled population (WHO, 2011) with unemployment rates almost doubled (OECD, 2010). This is in spite of a range of human rights and legislative arrangements at national and international level (ILO, 2017). Historically interventions for those with acquired health conditions and disabilities has been known as vocational rehabilitation: a multi-disciplinary practice often in response to industrial injury or trauma. As Fabian (2014) demonstrates this simple social re-integration model does not capture the complexity of the relations between work and disability.

Sexuality and gender identity: Minorities can be defined in terms of their sexual preference (for example, lesbian, gay, bisexual, pansexual or asexual), and/or in terms of their gender identity (for example, transgender, intersex). These groups represent a more recent focus in employment protection legislation, and in some nations substantive discrimination continues to be sanctioned by the state. These groups have received rather less attention in the career development literature. In addition to discrimination in employment recruitment, Anderson and Croteau (2014) identify difficulties in workplace relationships and workplace sexual identity management as salient issues. Heteronormativity, or assumptions of conformity to majority heterosexual societal norms represents a challenge to career development practice (Hancock, 2019).

This non-exhaustive list highlights some key social categories to consider, but may be inadequate to capture an individual's experience. Intersectionality must also be considered. Individuals are not identified by a single social marker, so they may simultaneously belong to multiple categories and perhaps face multiple disadvantage. Socially constructed identities may be contested. Each group in each location faces unique challenges. 


\section{Health and Well-Being Goals}

This category relates to UN Goal 3: Ensure healthy lives and promote well-being for all at all ages. Public policy related to careers development has largely ignored issues of health and well-being (Robertson, 2013a). A neglect of health is also evident in the literature on career development work. Individual counselling approaches to career development have been influenced by psychotherapy. Some authors have sought to import clinical practice to career counselling, or vice versa (Franklin \& Medvide, 2014). Others have stressed the commonalities and overlap between issues addressed in career counselling and personal/therapeutic counselling (Richardson, 1996; Zunker, 2008). The emergence of a wider literature on the relationship between work, health and public policy has to date had only a modest impact on career development practices. And yet it could be argued that positive well-being is an ultimate goal of all social interventions.

Robertson (2013b) argued that there were two likely mechanisms through which career development interventions may promote mental well-being. Firstly, guidance interactions incorporate factors with a short-term therapeutic effect, specifically a supportive relationship, recognising and building on existing strengths, promoting a future orientation, a goal focus, and a sense of personal agency. Secondly, career development interventions may promote enduring well-being through enabling sustainable work. Unemployment tends to be detrimental to mental health (Paul \& Moser, 2009; Waddell \& Burton, 2006). Conversely, work provides access to psycho-social factors that facilitate well-being (Warr, 2007), provided the work is of good quality. These benefits are likely to be enhanced where the work is of enduring interest and consistent with personal values - considerations that are central in career development work (Redekopp \& Huston, 2019). 
Health outcomes are intimately linked to socio-economic status, so any consideration of health and career development must encompass the relationship between work and health inequality (Robertson, 2014). There has been a growing recognition among public health specialists that work and education are factors that have a profound impact on population health, and on socio-economic status gradients in health outcomes (Bambra, 2011; Foresight Mental Capital and Wellbeing Project, 2008; Marmot, 2010; WHO, 2007). This has been slow to impact on thinking in the career development field, but Blustein (2008) has sought to highlight the links between work, health and public policy, and Robertson (2013a) has argued that career development work represents an unrecognised public health intervention. The recent emergence of the psychology of working perspective has located mental health at the heart of a contemporary approach to career development research (Duffy, Blustein, Diemer, Autin, 2016).

\section{Environmental Goals}

There is now widespread and growing international concern about environmental issues. 'Climate Change is the defining issue of our time and we are at a defining moment' (United Nations, n.d, p1). The UN Intergovernmental Panel on Climate Change (IPCC) seeks to coordinate international climate policy, and provides global leadership on this issue (see IPCC, 2019). There is a strong emphasis in the UN (2015) Sustainable Development Goals on the need to shift towards an environmentally sustainable society and economy, notably in Goal 13: Take urgent action to combat climate change and its impacts. In addition, goals 9, 12, 14, and 15 relate to industry specific activities to promote environmentally sustainable work. Issues of climate change, pollution, degradation of natural resources and habitats, and the loss of biodiversity have worldwide significance. The acknowledgement of the significant economic risks associated with climate change was signalled in the UK by the Stern report which concluded '...the benefits of strong and early action far outweigh the economic costs 
of not acting', (Stern, 2006, p. iv). It is the poor in developing economies that are most vulnerable to the early impacts of climate change and environmental degradation.

Plant $(2014 ; 2015)$ has led the way in articulating the need for career development to move away from promoting individualistic engagement with the economy towards a more collectively responsible vision of career development services that locates the environment as central to its concerns. Crucially he envisages a turn towards what he labels as 'green guidance' not as a superficial change in practice, but as a deep change in the philosophy of career development that gives ecology equal weighting with economy in policymaking. This call is taken up by Cohen-Scali et al. (2018) who identify environmental challenges, alongside demographic change as critical areas for career development policy and practice to respond to.

Responding to environmental challenges is not unproblematic for the career development profession, as there are different views on the urgency of environmental matters, and competing political visions of the priorities for action. Privileging one industry over another (such as green energy over fossil fuels) may present practitioners with challenges to their ethical frameworks or to relationships with key stakeholders. This concern can be overcome. Both governments and career services have had little hesitation in preferentially promoting career choices in science, technology engineering and mathematics (STEM) that are believed to be economically valuable, so the active promotion of a green economy is equally possible.

Environmental issues may become progressively more difficult to ignore. There is, however, little evidence to date that environmental considerations in career development have had a significant impact on national policymakers. There are recent signs that green guidance is 
beginning to become a mainstream concern for the career development profession, as evidenced by CERIC (2019) who produced a special issue on climate change of their Careering magazine for practitioners.

\section{Peace and Justice Goals}

This area has received little attention in the career development literature, so its inclusion requires some justification. It relates to UN Goal 16: Promote peaceful and inclusive societies for sustainable development, provide access to justice for all and build effective, accountable and inclusive institutions at all levels.

Whilst the notion of a peace may not seem obviously pertinent to career development, this linkage is an old idea. The pioneer of vocational guidance, Frank Parsons articulated a progressive vision in 'The philosophy of mutualism' where individual needs and community needs were compatible in a just, peaceful and prosperous society, supported by collective institutions (Gummere, 1988; O’Brien, 2001). Career services contribute to this objective by steering individuals towards their appropriate adult life role. More recently Plant (2014) and Cohen-Scali (2018) have found inspiration in Parson's utopian vision of mutualism.

Similarly, Pouyard and Guichard (2018) explicitly link social justice in the labour domain to peace and ecology.

Societies with gross economic inequalities, and high levels of structural unemployment are more vulnerable to civil unrest, and these issues can be aggravated by ethnic, nationalist or religious tensions. Young men, or indeed any citizens, who see no future for themselves and have a strong sense of unfairness, may find ways to express their frustration. Youth unemployment continues to be a global issue, with some regions, such as North Africa, facing a formidable challenge (ILO, 2018), and these regions may tend to be prone to 
political instability. There remains some debate as to the importance of unemployment and economic inequality as causal factors in the outbreak, duration and intensity of civil unrest; they probably interact with other local, social, political, and ecological factors (Couttenier \& Soubeyran, 2015).

At a societal level career development services working to improve access to decent work and reduce social inequity may potentially make a contribution to peace in the workplace, in places of learning, and in the community. This cannot be done in isolation; it is only viable if other social, educational and employment institutions are working together towards these aims. Educational institutions are not always a force for good in divided societies (Smith \& Vaux, 2003), but they can play an important role in post-conflict reconciliation, for example in Bosnia and Herzegovenia, and Northern Ireland (Emkic, 2018; Smith, 2010). The interconnected impact of policies and practices of economics, inequality, youth, and education is acknowledged by Sen (2007) in a report addressing peace and democracy in the Commonwealth nations. Career development interventions routinely operate in a space where these policies and practices interact. Arguably, career development services could make some level of contribution to social integration even where institutional systems are weak, but this has not been explored in the published literature.

The notion of career development work as a force for peace is complicated by the potential for a range of ethical orientations towards military (and security related) careers. Societies also vary in the extent to which they are militarised, with some enforcing conscription as a compulsory, albeit temporary, career choice. Armed forces can be seen as guarantors of peace, or as a threat to it. Intra-society peace does not necessarily mean peace with other 
nations or societies; on the contrary international aggression may be used by political leaders as a way to overshadow internal tensions.

There is another wider, yet more tangible contribution that should be considered: career services may have a role in reducing or preventing crime. There is a widespread belief that securing stable employment reduces criminal activity (Lageson \& Uggen, 2013). And yet offenders may face formidable barriers in the labour market, in addition to structural barriers that may affect any socio-economically disadvantaged population. Their employment prospects are shaped by employers' attitudes to crime. Rejection of ex-offenders in the early screening stages of personnel selection is widespread, and has led in the USA to the 'ban the box campaign' (Henry \& Jacobs, 2007), advocating the removal of questions on application forms requiring the disclosure of offences.

There are numerous examples of vocational rehabilitation interventions designed to support prisoners to find work. These are rarely in the form of isolated career counselling. More common is provision of vocational training, complemented by work placements, and job seeker advice and support. A career development programme may encompass these elements in addition to post release support. There is some evidence for the effectiveness of these programmes in achieving employment outcomes, but of greater interest here is the potential for such programmes to contribute to desistance from offending. Any factor that reduces reoffending is potentially of interest to policymakers.

The available literature reviews (such as Harrison \& Chehr, 2004; Vernick \& Reardon, 2001) and meta-analyses (Davis, Bozick, Steele, Saunders \& Miles, 2013; Wilson, Gallagher \& 
MacKenzie, 2000) suggest that vocational interventions reduce recidivism. These claims are made cautiously, as the available evidence is mixed, and limited by methodological weaknesses. The possibility of selection bias cannot be discounted: programme intakes may consist of those more willing and able to move away from crime. Conversely, where vocational programmes are reported as ineffective this may reflect poor programme design, or failure to provide adequate post-release support and follow up. Generally, success in finding employment is negatively associated with re-offending, at least in adults, so any successful employment support programme may make a contribution.

Whilst there is as yet an inadequate evidence base to draw firm conclusions, there are indicators that career development interventions may help offenders to find work and reduce recidivism. There is little reason to believe that policymakers have given serious consideration to the potential contribution of career development interventions to crime reduction. It is certain that no attention has been given to a vision for its role in crime prevention. Effective career development interventions could potentially steer people into education or roles in the legitimate economy that provide viable and sustainable alternatives to engaging in criminal careers, or gang membership. Prevention is of great value both socially and economically.

\section{Cross-cutting Themes}

Whilst it is useful to categorise policy goals into broad types, they remain strong interconnections between them. There may be synergies achieved where policy action in one domain has positive impacts in another domain. Three cross-cutting themes will be discussed here: social justice, sustainability, and societal change. 


\section{Social Justice}

Social justice is a politically and philosophically contested notion, with a complex relationship to career development (Hooley, Sultana \& Thomsen, 2017; Irving, 2005; Irving, in this volume; Sultana, 2014). Nonetheless it is relevant to all aspects of practice, and it is not confined to the social equity category of policy goals. Socio-economic status affects people's access to decent work, to educational opportunities, to health treatments and wellbeing outcomes, and their ability to avoid the consequences of ecological damage or involvement with the criminal justice system. Issues of social justice are central to career development work (IAEVG, 2013; McMahon, Arthur, Collins, 2008) and should infuse all the relevant public policy objectives.

\section{Sustainability}

The UN goals give prominence to sustainability. This term has become familiar from its ecological sense, but it is usefully ambiguous in that it has other meanings which cut across the policy categories. Sustainability simply means the potential to endure over time. This does not imply a static position; renewal and adaptation are necessary to survive. At an individual level, the notion of the sustainable career has been explored by De Vos, Dujardin and Meyers (2016), Heijden and De Vos (2015), and Newman (2011). De Vos, Dujardin, Gielens and Meyers (2016) explicitly suggest that the sustainable career needs to be put on the policymakers' agenda. Longer life spans mean potentially longer careers, and greater need for individuals to find ways to sustain a healthy relationship to work over longer time frames (Vuori, Blonk, \& Price, 2015). Institutions also need to be sustainable, and to renew themselves. At a societal level, as highlighted in UN Goals 8 and 11, communities and economic growth also need to be sustainable over time.

\section{Societal Change}


To a greater or lesser extent, all of the goals relate to bringing about positive change in society, or reducing negative outcomes. Conceptualising career development practitioners as agents of social change is nothing new; it is a theme in the work of the earliest pioneers of the field, such as Frank Parsons (O’Brien, 2001). A distinction can be made between a reactive and a proactive role for career development policy. A reactive approach would mean seeking to mitigate the economic and health effects of unemployment, or the consequences of environmental degradation, or the exclusion of minorities or offenders. A proactive approach would be to see career development policy as contributing to societal change - a position labelled as 'radical' by Watts (1996b, p354). This might mean adopting a preventive role, or driving and anticipating change. Proactive approaches are less common, and arguably present some ethical challenges in career counselling in terms of imposing the practitioners' social values on an individual service user. This dilemma is largely avoided if educational approaches are used with groups: raising awareness whilst respecting individual choice.

\section{Conclusion}

In recent years the widespread adoption of neoliberal models for economic governance has tended to focus career development services on a technocratic function: human capital development in support of economic growth. Career development services are used to serve the public policy objective of creating a skilled and adaptable labour force, directed towards industries with labour shortages. Governments have also, to a greater or lesser extent, sought to use career development services as a tool to promote equality in education and work, and occasionally to promote social mobility. The potential for career development work to bring about emancipatory social change is embraced by some scholars more enthusiastically than it is by governments. 
To date, studies of public policy in this field have provided frameworks that are predominantly descriptive. This is a sound starting point, but progress requires laying out the full range of potential policy goals - outlining the possibility space from which policy action can be selected. By drawing on the UN sustainable development goals, it is possible to extend our sense of the potential contribution of career related policy. The established three-fold distinction of economic, learning and social justice goals for career development policy can be expanded to a six-fold structure:

\section{Labour market goals}

2. Educational goals

3. Social equity goals

\section{Health and well-being goals}

5. Environmental goals

6. Peace and justice goals

In doing so, the neglected potential of health, environmental, and justice related goals are brought to the foreground. The role of career development services in supporting social justice, promoting sustainable lives and economies, and facilitating societal change cut across all six objectives.

There remain substantial barriers to realising this potential. Improved mental health, support for green industrial growth, and reductions in offending rates are rarely considered in careerrelated policy making. This is unfortunate as even modest progress on these outcomes is highly desirable. Responsibility for the governance of career services is almost always within departments tasked to deliver economic or educational objectives. In consequence the wider social benefits of career development work have yet to be fully realised. It will require clear communication to policymakers of a vision for the role of the career services of the future to overcome these problems. 


\section{References}

Ali, S.R. (2014). Poverty, social class and working. In D.L. Blustein (Ed.), The Oxford handbook of the psychology of working (pp.127-140). New York, NY: Oxford University Press.

Anderson, M.Z. \& Croteau, J.M. (2014). Towards and inclusive LGBT psychology of working. In D.L. Blustein (Ed.), The Oxford handbook of the psychology of working (pp.103126). New York, NY: Oxford University Press.

Arulmani, G. \& Kumar, S. (2009). Career and livelihood planning: Training manual. Bangalore, India: Jiva Project, The Promise Foundation.

Bambra, C. (2011). Work, worklessness and the political economy of health. Oxford, UK: Oxford University Press.

Bimrose, J. (2001). Girls and women: Challenges for career guidance practice. British Journal of Guidance and Counselling, 29, 79-94.

https://doi.org/10.1080/03069880020019392

Bimrose, J. (2004). Sexual harassment in the workplace: An ethical dilemma for career guidance? British Journal of Guidance and Counselling, 32, 109-123. https://doi.org/10.1080/03069880310001648049

Bimrose, J., Watson, M., McMahon, M., Haasler, S., Tomassini, M., \& Suzanne, P.A. (2014). The problem with women? Challenges posed by gender to career guidance practice. International Journal for Educational and Vocational Guidance, 14, 77-88. https://doi.org/ $10.1007 / \mathrm{s} 10775-013-9256-9$

Blustein, D.L. (2006). The psychology of working: A new perspective for career development, counselling and public policy. Mahwah, N.J: Lawrence Erlbaum. 
Blustein, D. L. (2008). The role of work in psychological health and well-being: A conceptual, historical and public policy perspective. American Psychologist, 63, 228-240. https://doi.org/10.1037/0003-066X.63.4.228

Blustein, D.L. (2014). The psychology of working: A new perspective for a new era. In D.L. Blustein (Ed.), The Oxford handbook of the psychology of working (pp.3-18). New York: Oxford University Press.

Brewer, J.M. (1942). History of vocational guidance. New York, NY: Harper.

CERIC (2019). Climate change and careers. Careering: Canada's magazine for career development professionals. Fall (special issue). Toronto: CERIC.

Cohen-Scali, V. (2018). Interventions in career design and education for the future. In: V. Cohen-Scali, J. Pouyaud, M. Podgórny, V. Drabik-Podgórna, G. Aisenson, J.L. Bernaud, I.A. Moumoula, \& J. Guichard (Eds.), Interventions in career design and education:

Transformation for sustainable development and decent work (pp 317-325). Cham, Switzerland: Springer.

Cohen-Scali, V., Guichard, J. Aisenson, G. Moumoula, I.A., Pouyaud, J. Drabik-Podgórna, V., ... Bernaud, J.L. (2018). The UNESCO Life Long Career Counseling Chair Project: Main Purposes and Implemented Actions. In: V. Cohen-Scali, J. Pouyaud, M. Podgórny, V. Drabik-Podgórna, G. Aisenson, J.L.Bernaud, I.A., ... J. Guichard (Eds.) Interventions in Career Design and Education: Transformation for Sustainable Development and Decent Work (pp1-11). Cham, Switzerland: Springer.

Couttenier, M. \& Soubeyran, R. (2015). A survey of the causes of civil conflicts: Natural and economic conditions. Revue d'Économie Politique, 6, 787-810. 
Davis, L. M., Bozick, R., Steele, J. L., Saunders, J., \& Miles, J. N. V. (2013). A meta-analysis of programs that provide education to incarcerated adults. Santa Monica, CA: Rand Corporation.

De Vos, A., Dujardin, J-M., \& Meyers, C. (2016). Conceptual Framework for sustainable careers. In: A. De Vos, J-M. Dujardin, T. Gielens, \& C. Meyers, Developing sustainable careers across the lifespan. European Social Fund Network on 'Career and AGE (Age, Generations, Experience) (pp.9-28). Cham, Switzerland: Springer.

De Vos, Dujardin, J-M., Gielens, T., \& Meyers (2016). Facilitating sustainable careers: Getting started. In A. De Vos, J-M. Dujardin, T. Gielens \& C.Meyers, Developing sustainable careers across the lifespan. European Social Fund Network on 'Career and AGE (Age, Generations, Experience) (pp.91-97). Cham, Switzerland: Springer.

Duffy, R., Blustein, D. L., Diemer, M. A., \& Autin, K. L. (2016). The psychology of working theory. Journal of Counseling Psychology, 63, 127-148. https://doi.org/10.1037/cou0000140 Emkic, E. (2018). Reconciliation and Education in Bosnia and Herzegovina: From Segregation to Sustainable Peace. Cham, Switzerland: Springer.

European Union (2017). The new European consensus on development 'our world, our dignity, our future' joint statement by the Council and the representatives of the governments of the member states meeting within the Council, the European Parliament and the European Commission. Brussels, Belgium: EU.

Fabian, E. (2014). Work and disability. In D.L. Blustein (Ed.), The Oxford handbook of the psychology of working (pp.185-200). New York, NY: Oxford University Press.

Flores, L.Y. (2014). Race and working. In D.L. Blustein (Ed.), The Oxford handbook of the psychology of working (pp.71-84). New York, NY: Oxford University Press. 
Foresight Mental Capital and Wellbeing Project. (2008). Final report. London, UK: The Government Office for Science.

Franklin, A.J., \& Medvide, M.B. (2014). Psychotherapy and the integration of the psychology of working into therapeutic practices. In D.L. Blustein (Ed.), The Oxford Handbook of the Psychology of Working (pp.252-270). New York: Oxford University Press.

Gummere, R.M. (1988). The counsellor as prophet: Frank Parsons, 1854-1908. Journal of Counseling and Development, 66, 402-405. https://doi.org/10.1002/j.1556-

6676.1988.tb00899.x

Hancock, A. (2019). The career development of lesbians, gay men and bisexuals. Journal of the National Institute of Career Education and Counselling, 42, 47-55.

https://doi.org/10.20856/jnicec.4208

Harrison, B., \& Schehr, R.C. (2008). Offenders and post-release jobs. Journal of Offender Rehabilitation, 39, 3, 35-68. https://doi.org/10.1300/J076v39n03_03

Heijden, B.I.J.M. \& De Vos, A. (2015). Sustainable careers: Introductory chapter. In A. De Vos, \& B.I.J.M. Heijden (Eds.), Handbook of research on sustainable careers (pp.1-20). Cheltenham: Edward Elgar.

Henry, J.S., \& Jacobs, J.B. (2007). Ban the box to promote ex-offender employment. Criminology and Public Policy, 6, 755-762. https://doi.org/10.1111/j.1745-

\section{$\underline{9133.2007 .00470 . x}$}

Hooley, T., Sultana, R., \& Thomsen, R. (2017) The neoliberal challenge to career guidance mobilising research, policy and practice around social justice. In T. Hooley, R.G. Sultana \& R. Thomsen (Eds.), Career guidance for social justice: Contesting neoliberalism (pp.1-28). London: Routledge. 
IAEVG (2013). Communiqué on social justice in educational and career guidance and counselling. Montpellier, France: International Association for Educational and Vocational Guidance.

ICCDPP (2019). Communiqué 2019. Leading career development services into an uncertain future: Ensuring access, integration and innovation. Troms $\emptyset$, Norway: International Centre for Career Development in Public Policy.

ILO (2014). Promoting equity. Ethnic diversity in the workplace: a step-by-step guide. Geneva: International Labour Organisation.

ILO (2017). Decent work for persons with disabilities: promoting rights in the global development agenda. Geneva: International Labour Organisation.

ILO (2018). World employment social outlook: Trends 2018. Geneva: International Labour Organisation.

IPCC (2019). Special report: Global warming of $1.5^{\circ}$ C. Summary for policymakers. New York, NY: United Nations Intergovernmental Panel on Climate Change.

Irving, B. (2005). Social justice: A context for career education and guidance. In B. Irving \& B. Malik (Eds.), Critical reflections on career education and guidance: Promoting social justice within a global economy (pp. 10-24). London: Routledge.

Irving, B.A. (2018). The pervasive influence of neoliberalism on policy guidance discourses in career/education: Delimiting the boundaries of social justice in New Zealand. In T. Hooley, R.G. Sultana, \& R.Thomsen (Eds.), Career guidance for social justice: Contesting neoliberalism (pp.47-62). London: Routledge. 
Kantamneni, N. (2014). Gender and the psychology of working. In D.L. Blustein (Ed.), The Oxford handbook of the psychology of working (pp.85-102). New York, NY: Oxford University Press.

Killeen, J., Watts, A.G., \& Kidd, J. (1999). Social benefits of career guidance. NICEC briefing. Cambridge, UK: National Institute for Career Education and Counselling.

Lageson, S., \& Uggen, C. (2013). How work affects crime - and crime affects work - over the life course. In C.L. Gibson \& M.D. Krohn (Eds.), Handbook of life course criminology (pp. 201-212). Cham, Switzerland: Springer.

Launikari,M., Lettmayr, C., \& van Loo, J. (2011). Ageing Europe at work - Guidance to support longer careers of ageing workers. In: CEDEFOP, Working and ageing: Guidance and counselling for mature learners (pp.208-290). Luxembourg: European Union.

Marmot, M. (2010). Fair society, healthy lives: Strategic review of health inequalities in England post 2010. London: The Marmot Review. Retrieved from http://www.marmotreview.org

McMahon, M., Arthur, N., \& Collins, S. (2008). Social justice and career development: Looking back, looking forward. Australian Journal of Career Development, 17, 21-29. Newman, K.L. (2011). Sustainable careers: Lifecycle engagement in work. Organizational Dynamics 40, 136-143. https://doi.org/10.1016/j.orgdyn.2011.01.008

Newman, A., Bimrose, J., Nielsen, I., \& Zacherd, H. (2018). Vocational behavior of refugees: How do refugees seek employment, overcome work-related challenges, and navigate their careers? Journal of Vocational Behavior, 105, 1-5. https://doi.org/10.1016/j.jvb.2018.01.007 
O’Brien, K.M. (2001). The legacy of Parsons: Career counsellors and vocational psychologists as agents of social change. Career Development Quarterly, 50, 66-76. https://doi.org/10.1002/j.2161-0045.2001.tb00891.x

OECD (2004). Career guidance and public policy: Bridging the gap. Paris: Organization for Economic Co-operation and Development.

OECD (2010). Sickness, disability and work: breaking the barriers. A synthesis of findings across OECD countries. Paris: Organisation for Economic Co-operation and Development Paul, K.I., \& Moser, K. (2009). Unemployment impairs mental health: Meta-analyses. Journal of Vocational Behaviour, 74, 264-282. https://doi.org/10.1016/j.jvb.2009.01.001

Peck, D. (2004). Careers services: History, policy and practice in the United Kingdom. London: RoutledgeFalmer.

Piketty, T. (2014). Capital in the twenty first century. Cambridge, MA: Belknap Press.

Plant, P. (2014). Green guidance. In G.Arulmani, A. J. Bakshi, F.T.L. Leong, \& T. Watts (Eds.), Handbook of career development: International perspectives (pp. 309- 316). Cham, Switzerland: Springer.

Plant, P. (2015). Green guidance: Guidance for the future. Revista Española de Orientación y Psicopedagogía, 26, 115-123.

Pouyard, J., \& Guichard, J. (2018). A twenty-first century challenge: How to lead an active life whilst contributing to sustainable and equitable development. In T. Hooley, R.G. Sultana, \& R. Thomsen (Eds.), Career guidance for social justice: Contesting neoliberalism, (pp.31-46). London: Routledge. 
Redekopp, D.E., \& Huston, M. (2019). The broader aims of career development: Mental health, wellbeing and work. British Journal of Guidance and Counselling, 47, 246-257. https://doi.doi.org/10.1080/03069885.2018.1513451

Richardson, M. S. (1996). From career counselling to counselling/psychotherapy for work, jobs and career. In M. L. Savickas, \& B. W. Walsh (Eds.), Career counselling theory and practice (pp. 347-360). Palo Alto, CA: Davies-Black.

Roberts, K. (2005). Social class, opportunity structures and career guidance. In B. Irving \& B. Malik (Eds.), Critical reflections on career education and guidance: Promoting social justice within a global economy (pp. 130-142). London: Routledge.

Robertson, P. J. (2013a). Career guidance and public mental health. International Journal for Educational and Vocational Guidance, 13, 151-164. https://doi.org/10.1007/s10775-013$\underline{9246-\mathrm{y}}$

Robertson, P. J. (2013b). The well-being outcomes of guidance. British Journal of Guidance and Counselling, 41, 254-266. https://doi.org/10.1080/03069885.2013.773959

Robertson P.J. (2014). Health inequality and careers. British Journal of Guidance and Counselling, 42, 338-351. https://doi.org/10.1080/03069885.2014.900660

Savickas, M.L. (2008). Helping people choose jobs: A history of the guidance profession. In J.A. Athanasou \& R. van Esbroeck (Eds.), International handbook of career guidance (pp.97113). Dordrecht, Netherlands: Springer.

Savickas, M.L. (2009). Pioneers of the vocational guidance movement: A centennial celebration. Career Development Quarterly. 57, 194-198.

Sen, A. (2007). Peace and democratic society. Cambridge: Open Book Publishers. 
Smith, A. (2010). The influence of education on conflict and peace building. (Background paper for the Education for All Global Monitoring Report 011/ED/EFA/MRT/PI/48). Paris: United Nations Educational, Scientific and Cultural Organisation (UNESCO)

Smith, A. \& Vaux, T. (2003). Education, conflict and international development. London: Department for International Development.

Stern, N. (2006). Stern review on the economics of climate change. London: HM Treasury.

Sterns, H.L. \& Sterns, A.A. (2014). Approaches to ageing and work. In D.L. Blustein (Ed.) The Oxford handbook of the psychology of working (pp. 160-184). New York, NY: Oxford University Press.

Stiglitz, J. E. (2013). The price of inequality. London: Penguin.

Sultana, R. G. (2004). Guidance policies in the knowledge society: Trends, challenges and responses across Europe. Thessaloniki, Greece: CEDEFOP.

Sultana, R.G. (2014). Pessimism of the intellect, optimism of the will? Troubling the relationship between career guidance and social justice. International Journal for Educational and Vocational Guidance, 14, 5-19. https://doi.org/10.1007/s10775-013-9262-y

Sultana, R.G. (2017). Anchoring career guidance in the Mediterranean? In search of southern perspectives. In R.G. Sultana (Ed.), Career guidance and livelihood planning across the Mediterranean: Challenging transitions in South Europe and the MENA region (pp.3-15). Rotterdam: Sense.

United Nations (2015). Transforming our world: The 2030 Agenda for Sustainable Development. Resolution adopted by the General Assembly 70/1. New York: United Nations. 
United Nations (n.d.). Climate change. Retrieved from:

https://www.un.org/en/sections/issues-depth/climate-change/

Vernick, S.H., \& Reardon, R.C. (2001). Career development programs in corrections. Journal of Career Development, 27, 265-277. https://doi.org/10.1177/089484530102700403

Vuori J., Blonk R., \& Price R.H. (2015). Conclusions for policy, practice and research. In: Vuori J., Blonk R., \& Price R. (Eds.), Sustainable working lives. aligning perspectives on health, safety and well-being (pp. 291-300). Dordrecht, Netherlands: Springer.

Waddell, G., \& Burton, A. K. (2006). Is work good for your health and well-being? London, UK: Department for Work and Pensions.

Warr, P. (2007). Work, happiness and unhappiness. Mahwah, NJ: Lawrence Erlbaum.

Watts, A.G. (1996a). Career guidance and public policy. In A.G. Watts, B. Law, J. Killeen, J.M. Kidd, \& R. Hawthorn, Rethinking careers education and guidance: Theory, policy and practice (pp 380-391). London: Routledge.

Watts, A.G (1996b). Socio-political ideologies in guidance. In A.G. Watts, B. Law, J. Killeen, J.M. Kidd \& R. Hawthorn, Rethinking careers education and guidance: Theory, policy and practice (pp. 351-365). London: Routledge.

Watts, A.G. (2008). Career guidance and public policy. In J.A. Athanasou and R. van Esbroeck (Eds.), International handbook of career guidance (pp. 341- 353). Dordrecht, Netherlands: Springer.

Watts, A.G. (2009). The relationship of career guidance to VET. Cambridge: NICEC/OECD. Watts, A. G., \& Fretwell, D. (2004). Public policies for career development: Policy strategies for designing career information and guidance systems in middle-income and transition economies. Washington, DC: World Bank. 
Watts, A. G., \& Sultana, R. (2004). Career guidance policies in 37 countries: Contrasts and common themes. International Journal for Vocational and Educational Guidance, 4, 105122. https://doi.org/10.1007/s10775-005-1025-y

WHO (2007). Employment conditions and health inequalities: Final report to the WHO commission on social determinants of health. Geneva: World Health Organisation.

WHO (2011). World report on disability (summary). Geneva: World Health Organisation.

Wilson, D.B., Gallagher, C.A.,\& MacKenzie, D.L. (2000). A meta-analysis of correctionsbased education, vocation and work programs for adult offenders. Journal of Research in Crime and Delinquency, 37, 347-368. https://doi.org/10.1177/0022427800037004001

Zunker, V. (2008). Career, work and mental health: Integrating career and personal counseling. London, UK: Sage. 